\title{
Elektrody symulujące jako narzędzie do badań skuteczności ochrony katodowej stalowych konstrukcji
}

\begin{abstract}
Pomiary skuteczności ochrony katodowej stalowych konstrukcji zakopanych w ziemi lub zanurzonych w wodzie mają kluczowe znaczenie dla bezpieczeństwa ich użytkowania. Jednym z elementów służących do prawidłowej oceny skuteczności ochrony katodowej są elektrody symulujące, które stanowią ważne ogniwo w ustaleniu przyczyn korozji konstrukcji, stopnia zagrożenia korozyjnego oraz wyboru środków ochrony. Elektrody symulujące są niezbędnym narzędziem służącym do pomiarów potencjału konstrukcji wolnego od składowej omowej (IR) oraz ustalenia stref występowania oddziaływania obcych prądów błądzących.
\end{abstract}

Słowa kluczowe: elektroda symulująca, składowa omowa, potencjał, prąd, gęstość prądu.

\section{Simulating electrodes as a tool for testing the effectiveness of cathodic protection of steel structures}

\begin{abstract}
Measurements of the effectiveness of the cathodic protection of steel structures buried in the ground or submerged in water, are essential for the safe operation of these facilities. One of the elements for correct assessment of the effectiveness of cathodic protection are simulating electrodes, which are an important link in determining the causes of corrosion of the structure, the degree of danger of corrosion and the choice of means of protection. The simulating electrodes are an indispensable tool for measuring the potential of the structure, free of the ohmic component (IR) and for measurements to determine the presence of zones of influence of foreign stray currents.
\end{abstract}

Key words: simulates electrode, ohmic component, potential, current, current density.

\section{Konieczność wykonywania pomiarów potencjałów z wyłączeniem składowej omowej}

Wyróżnia się trzy rodzaje ochrony katodowej: skuteczną, niepełną i nieskuteczną. Ochrona katodowa jest skuteczna wówczas, gdy zapewnia właściwą ochronę w miejscach występowania na powierzchni gazociągu ubytków (defektów) powłoki ochronnej. O niepełnej ochronie katodowej będziemy mówić wtedy, gdy nie zapewnia ona spełnienia kryterium ochrony katodowej we wszystkich miejscach defektów powłoki, a o ochronie nieskutecznej - gdy nie ma ona wystarczającego zasięgu [1].

O szybkości korozji metalu w elektrolicie decyduje kinetyka procesów elektrodowych: depolaryzacyjnych i polaryzacyjnych przebiegających podczas normalnej pracy ogniw korozyjnych, jak też wymuszonych przez celową polaryzację zewnętrzną (katodową) bądź też przez prądy błądzące. Miarą szybkości korozji w danym układzie jest wartość prądu płynącego przez granicę faz metal-elektrolit. Natomiast wartość potencjału elektrody określa stan termodynamiczny procesu elektrodowego (korozja, odporność, pasywacja). Przy braku oddziaływania prądu zewnętrznego, potencjał konstrukcji jest tzw. potencjałem spoczynkowym $U_{S}$.

Metal chroniony katodowo przyjmuje potencjał polaryzacji $U_{P}$ bardziej ujemny od potencjału spoczynkowego, bowiem do wartości $U_{S}$ dodaje się wartość napięcia będącego miarą polaryzacji aktywacyjnej i stężeniowej $\Delta U_{P}$ oraz omowej $\Delta U_{I R}$. Metal podlegający oddziaływaniu prądu błądzącego przyjmuje potencjał różny od potencjału spoczynkowego: bardziej 
dodatni, jeżeli prąd błądzący wypływa z metalu, względnie bardziej ujemny, jeśli prąd błądzący wpływa do metalu.

Różnica potencjałów odniesienia rurociąg-elektroda reprezentuje potencjał elektrochemiczny rurociągu jedynie wówczas, gdy nie jest on poddany działaniu prądu zewnętrznego w miejscu wykonywania pomiaru. Natomiast w warunkach ochrony katodowej lub w warunkach przepływu prądu błądzącego przez granicę faz metal-elektrolit do wartości potencjału elektrochemicznego metalu $\left(U_{S}+\Delta U_{P}=U_{P}\right)$ dodaje się wartość spadku napięcia w elektrolicie $\left(\Delta U_{I R}\right)$, czyli polaryzację omową [8]:

$$
U_{\text {on }}=U_{S}+\Delta U_{P}+\Delta U_{I R}=U_{P}+\Delta U_{I R}
$$

gdzie: $U_{o n}$ - potencjał konstrukcji mierzony w warunkach przepływu zewnętrznego prądu elektrycznego, tzw. potencjał załączeniowy.

O wartości spadku napięcia w elektrolicie $\Delta U_{I R}$ decydują: jakość pokrycia ochronnego oraz rezystywność gruntu. Na powierzchniach niewielkich nieszczelności w szczelnym pokryciu gęstość prądu osiąga duże wartości, spadek napięcia w przylegającym elektrolicie jest więc na ogół większy niż w pobliżu dużego defektu w pokryciu złej jakości. Polaryzacja omowa fałszuje obraz ochrony katodowej konstrukcji i nie świadczy o stanie ochrony konstrukcji. Jeżeli celem pomiaru potencjału jest ocena skuteczności ochrony katodowej, to składowa IR powinna być wyeliminowana z mierzonej wartości potencjału. Natomiast w przypadku, gdy pomiary potencjałów wykonuje się w celu określenia stopnia zagrożenia korozyjnego, to dla ustalenia położenia stref anodowych i katodowych na konstrukcji, spowodowanych oddziaływaniem prądu błądzącego, należy mierzyć wartości potencjałów zawierające składową IR.

Gazociąg, w którym prąd błądzący osiąga dużą gęstość na małej powierzchni defektu, może być bardziej zagrożony korozją niż gazociąg o średniej jakości powłoki, gdzie prąd błądzący rozkłada się na powierzchni wielu defektów [2].

Potrzeba eliminacji składowej IR z mierzonej wartości potencjału chronionej katodowo konstrukcji wynika nie tylko z potrzeby określenia skuteczności ochrony konstrukcji, lecz także z obawy jej przechronienia. Przechronienie katodowe konstrukcji może doprowadzić do kruchości wodorowej stali oraz odrywania się pokrycia ochronnego wskutek penetracji wilgoci (elektroosmoza) [3]

\section{Rodzaje konstrukcji elektrod symulujących}

Elektrody symulujące można podzielić na elektrody przenośne i elektrody stałe. Zasady ich działania są takie same, różnią się od siebie zastosowaniem oraz konstrukcją.

\section{Przenośne elektrody symulujące}

Elektrody symulujące przenośne najczęściej mają kształt stalowego pręta zaostrzonego na końcu w postaci grotu z eksponowaną powierzchnią stalową (rysunek 1).

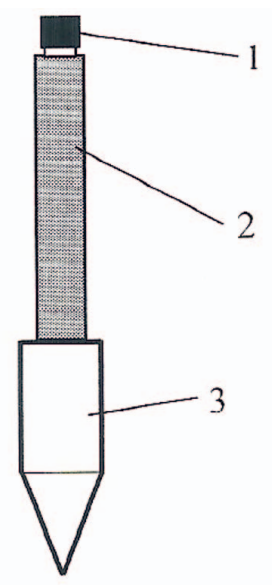

Rys. 1. Przykład rozwiązania technicznego przenośnej elektrody symulującej [7]

1 - zacisk łączeniowy przewodu elektrycznego, 2 - izolowany korpus elektrody, 3 - stalowy grot pomiarowy o znanej powierzchni

\section{Stałe elektrody symulujące}

Stałe elektrody symulujące można podzielić na elektrody:

- zintegrowane,
- niezintegrowane.

Elektrody zintegrowane zbudowane są z elektrody odniesienia i elektrody symulującej o znanej powierzchni. Powierzchnia symulująca defekt powłoki oraz elektroda odniesienia tworzą scaloną konstrukcję.

Na rysunku 2 przedstawiono schemat płaskiej elektrody symulującej o znanej powierzchni.

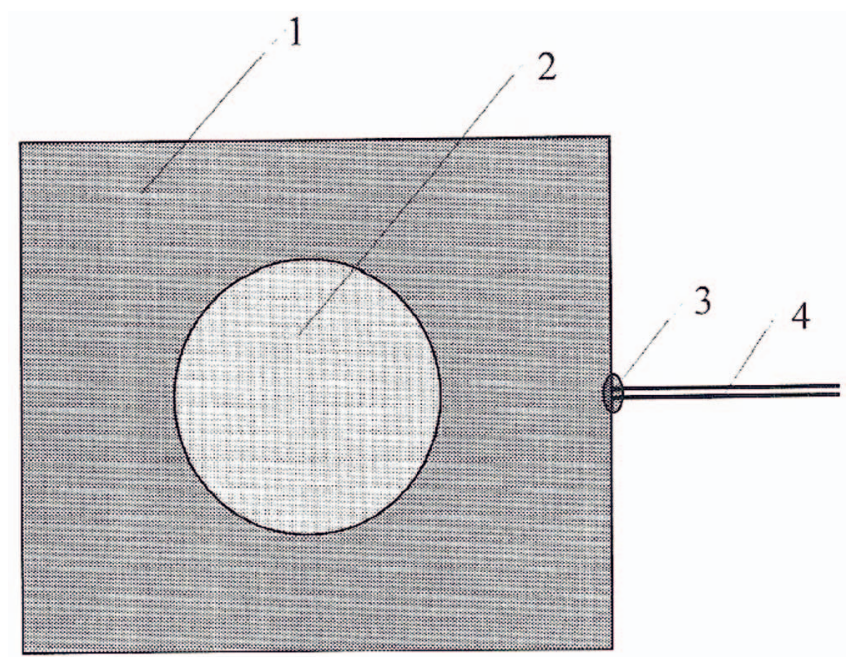

Rys. 2. Elektroda symulująca do montażu na stałe w ziemi [7]

1 - zaizolowana stalowa powierzchnia płytki, 2 - niezaizolowana stalowa powierzchnia płytki, 3 - zaizolowane miejsce połączenia płytki z przewodem elektrycznym, 4 - przewód elektryczny 


\section{Schematy pomiarowe i zasady stosowania elektrod symulujących}

W pomiarach korozyjnych podziemnych stalowych konstrukcji stosuje się schemat oparty na pomiarach potencjału i prądu na powierzchni symulującej określony defekt (rysunek 3).

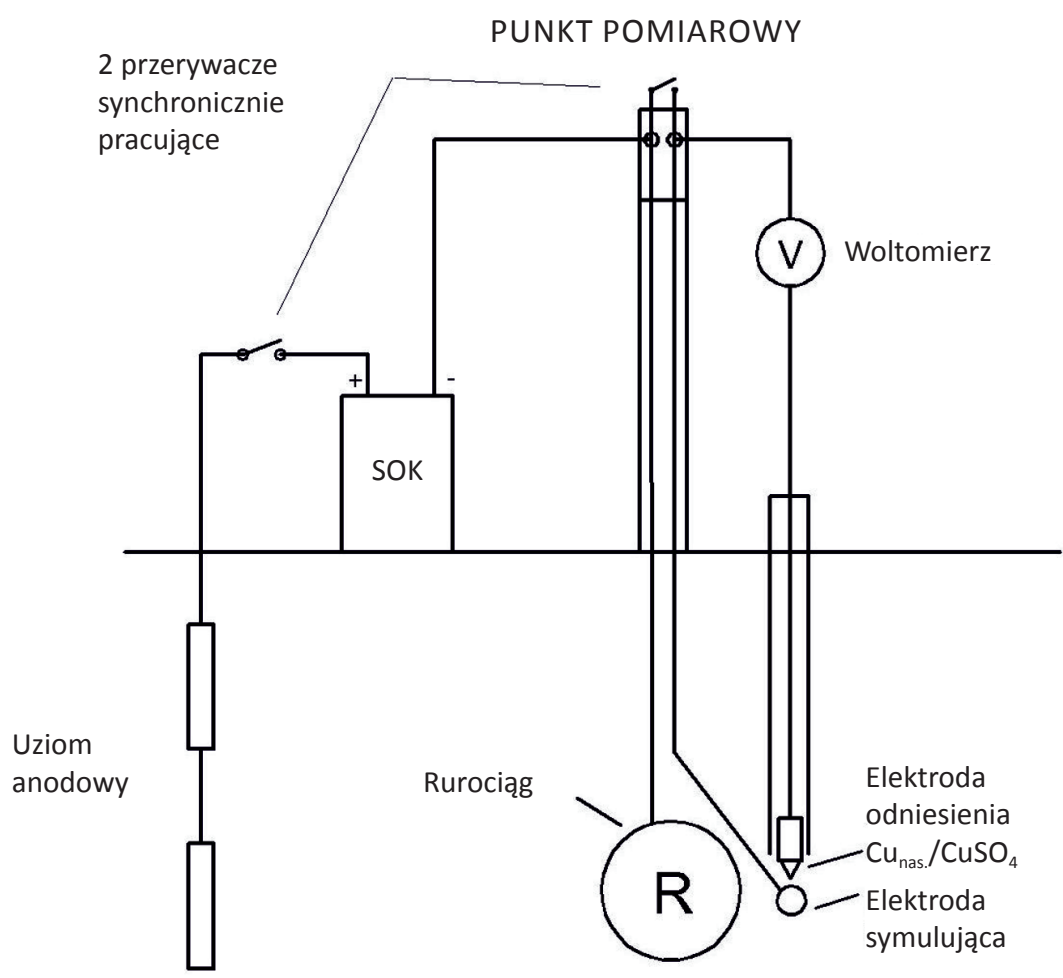

Rys. 3. Schemat pomiaru potencjału gazociągu i powierzchni symulującej [4] kość prądu potrzebną do spolaryzowania stalowej powierzchni defektu w izolacji o danej powierzchni.

Innym schematem pomiarowym, w którym ustala się skuteczność ochrony katodowej badanej konstrukcji, jest pomiar i rejestracja potencjału i prądu przy taktującej ochronie katodowej (rysunek 4).

Pomiary polegają na podłączeniu zsynchronizowanych ze sobą przerywaczy pracujących w trybie on/off (w określonym cyklu, np. 27/3 s) w obwód ochrony katodowej oraz w obwód połączeniowy powierzchni symulującej i badanej konstrukcji i określeniu ich potencjałów, a także prądu płynącego między konstrukcją a powierzchnią symulującą.

Podczas cyklu ,załącz” prąd ochrony katodowej polaryzuje badaną konstrukcję i podłączoną do niej nieizolowaną powierzchnię defektu symulującego. W trakcie jednoczesnego odłączenia prądu ochrony katodowej (płynącego do badanej konstrukcji) i powierzchni symulującej następuje pomiar potencjałów odłączeniowych wolnych od składowej omowej badanej konstrukcji i stalowego defektu symulującego [5]. Pomiar potencjału odłączeniowego badanej konstrukcji i powierzchni symulującej pozwala na ocenę skutecz-

Zasadą takich pomiarów jest jednoczesna rejestracja i pomiary: potencjału chronionej katodowo konstrukcji, potencjału powierzchni symulującej połączonej z konstrukcją oraz prądu płynącego między powierzchnią symulującą a konstrukcją. Pomiary polegają na odłączeniu powierzchni symulującej od badanej konstrukcji i analizie potencjałów konstrukcji i powierzchni symulującej bezpośrednio po ich rozłączeniu. Na podstawie analizy potencjału odłączeniowego powierzchni symulującej, wolnego od składowej omowej, można stwierdzić, czy defekty mniejsze lub równe badanej powierzchni symulującej spełniają kryterium ochrony założone przed rozpoczęciem pomiarów.

Analizie poddaje się również potencjał konstrukcji, który bezpośrednio po odłączeniu może obrazować stan jej izolacji w pobliżu miejsca wykonywania pomiarów. Jeżeli potencjał wzrośnie w kierunku elektroujemnym, będzie to oznaczać, że w okolicy miejsca pomiarów powierzchnia defektów jest mniejsza niż powierzchnia defektu symulującego. Natomiast, jeśli potencjał nie ulegnie zmianie, defekty badanej konstrukcji w okolicy miejsca pomiaru mają większą powierzchnię niż odłączona powierzchnia symulująca.

Wartość natężenia prądu płynącego między badaną konstrukcją a powierzchnią defektu symulującego obrazuje wiel- ności ochrony katodowej według założonego potencjałowego

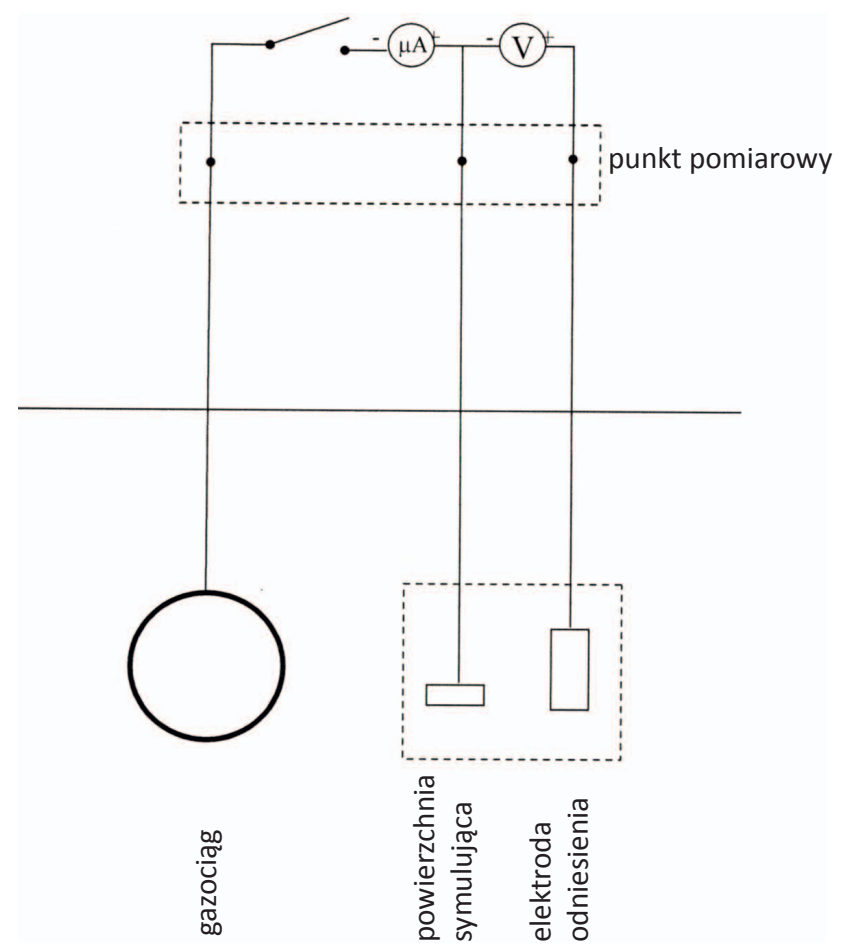

Rys. 4. Schemat pomiaru potencjału gazociągu oraz potencjału i prądu powierzchni symulującej [7] 
kryterium ochrony. Prąd płynący podczas załączenia ochrony katodowej pomiędzy powierzchnią symulującą a badaną konstrukcją jest miarą ilości prądu potrzebnego do polaryzacji defektu symulującego konstrukcji stalowej o danej nieizolowanej powierzchni oraz miarą ilości prądu potrzebnego do polaryzacji defektów izolacji badanego obiektu o powierzchni mniejszej od nieizolowanej powierzchni symulującej.

W pomiarach potencjału powierzchni symulujących istnieje zasada, że dziesięciokrotne zwiększenie powierzchni defektu w pokryciu izolacji odpowiada dwukrotnemu zmniejszeniu gęstości prądu. Dlatego - chcąc przekonać się, czy defekty o większych powierzchniach niż defekt symulujący są również chronione katodowo, spełniając jednocześnie założone kryterium ochrony katodowej - montujemy rezystor na przewodzie łączącym gazociąg i powierzchnię symulującą oraz zmniejszamy dwukrotnie wartość płynącego prądu. Jeżeli zmierzony potencjał nie ulegnie zmianie na bardziej elektroujemny, to defekty dziesięciokrotnie większe od próbnego nie spełnią kryterium ochrony [1].

Czas rejestracji pomiarów powinien być tak dobrany, aby późniejsza analiza wyników pozwalała na badanie kilku cyklów on/off ochrony katodowej.

Na jakość pomiarów ma wpływ miejsce usytuowania elektrody odniesienia i powierzchni elektrody symulującej.

Według schematów pomiarowych przedstawionych na rysunkach 3 i 4 elektroda symulująca oraz elektroda odniesienia może zostać usytuowana bezpośrednio w ziemi przy badanym gazociągu, w pewnej odległości nad badanym gazociągiem lub tuż nad gazociągiem na powierzchni ziemi. Sama powierzchnia defektu symulującego też może zostać zainstalowana w dowolnej odległości od gazociągu, ale - jak wykazuje praktyka pomiarowa - najlepiej jest zainstalować powierzchnię symulującą tuż przy samym gazociągu, a elektrodę odniesienia bezpośrednio nad badaną powierzchnią defektu symulującego. Im mniejsza będzie odległość między zainstalowaną powierzchnią symulującą a elektrodą odniesienia, tym mniejszy będzie wpływ prądów błądzących na badany potencjał, np. prądu ochrony katodowej czy też prądu wyrównawczego płynącego z pobliskich torów trakcji kolejowej. Na wielkość potencjału odłączeniowego powierzchni symulującej, w przypadku pierwszego schematu pomiarowego, ma wpływ przede wszystkim prąd ochrony katodowej, który fałszuje mierzony gradient potencjału. W przypadku drugiego schematu pomiarowego możemy ograniczać wpływ ochrony katodowej na mierzony gradient potencjału. W tym celu ustawiamy ochronę katodową w cykl pracy on/off i w momencie, gdy następuje wyłączenie ochrony katodowej oraz jednoczesne odłączenie powierzchni symulującej od badanej konstrukcji, mierzymy potencjał, który nie jest zafałszowany prądem ochrony katodowej. Ten sposób pomiaru oraz minimalna możliwa odległość pomiędzy elektrodą odniesienia i powierzchnią elektrody symulującej pozwala maksymalnie zmniejszyć wpływ prądów błądzących płynących w ziemi na mierzony potencjał.

\section{Przykładowe obliczenie wymaganej gęstości prądu na powierzchni elektrody symulującej oraz wymaganego potencjału załączeniowego}

Do symulacji obliczeń wybrano duży obiekt $\mathrm{z}$ rozwiniętą infrastrukturą, którego powierzchnia podziemnych gazociągów wynosi $5000 \mathrm{~m}^{2}$.

\section{Przypadek 1}

Założenie: powłoka ochronna gazociągów jest bezdefektowa, jedyne defekty to powierzchnie zainstalowanych elektrod symulujących w liczbie:

\section{0 elektrod $10 \mathrm{~cm}^{2}$ i 3 elektrody $1 \mathrm{~cm}^{2}$}

Obliczenia rezystancji defektu:

$$
R_{d}=\frac{\rho}{2 D}\left(1+\frac{8 d}{\Pi D}\right) \Omega
$$

gdzie:

$\rho$ - rezystywność gruntu $[\Omega \mathrm{m}]$,

$D$ - średnica defektu [m],

dla defektów elektrod symulujących według (2), dla $d=0 \mathrm{~mm}$.
Dla defektu $10 \mathrm{~cm}^{2}(D=3,57 \mathrm{~cm})$ i $\rho=100 \Omega \mathrm{m}$ :

$$
R_{d 10}=1400 \Omega
$$

Dla defektu $1 \mathrm{~cm}^{2}(D=1,128 \mathrm{~cm})$ i $\rho=100 \Omega \mathrm{m}$ :

$$
\begin{gathered}
R_{d 1}=4433 \Omega \\
R_{d 10 \mathrm{wyp}}=1400: 10=140 \Omega \\
R_{d 1 \mathrm{wyp}}=4433: 3=1478 \Omega
\end{gathered}
$$

Średnia jednostkowa rezystancja przejścia wszystkich defektów:

$$
R_{p}=128 \cdot \mathrm{S}=128 \cdot 5000=6,4 \cdot 10^{5} \Omega \mathrm{m}^{2}
$$

Odpowiada jej średnia gęstość prądu ochrony katodowej odczytana z załączonego wykresu $j=f\left(R_{p}\right)$ :

$$
J_{\dot{s} r}=0,0014 \mathrm{~mA} / \mathrm{m}^{2}
$$

Zapotrzebowanie prądu ochrony katodowej:

$$
I=0,0014 \cdot 5000=7,0 \mathrm{~mA}
$$


Tablica 1. Wyniki obliczeń dla przypadków 2 i 3

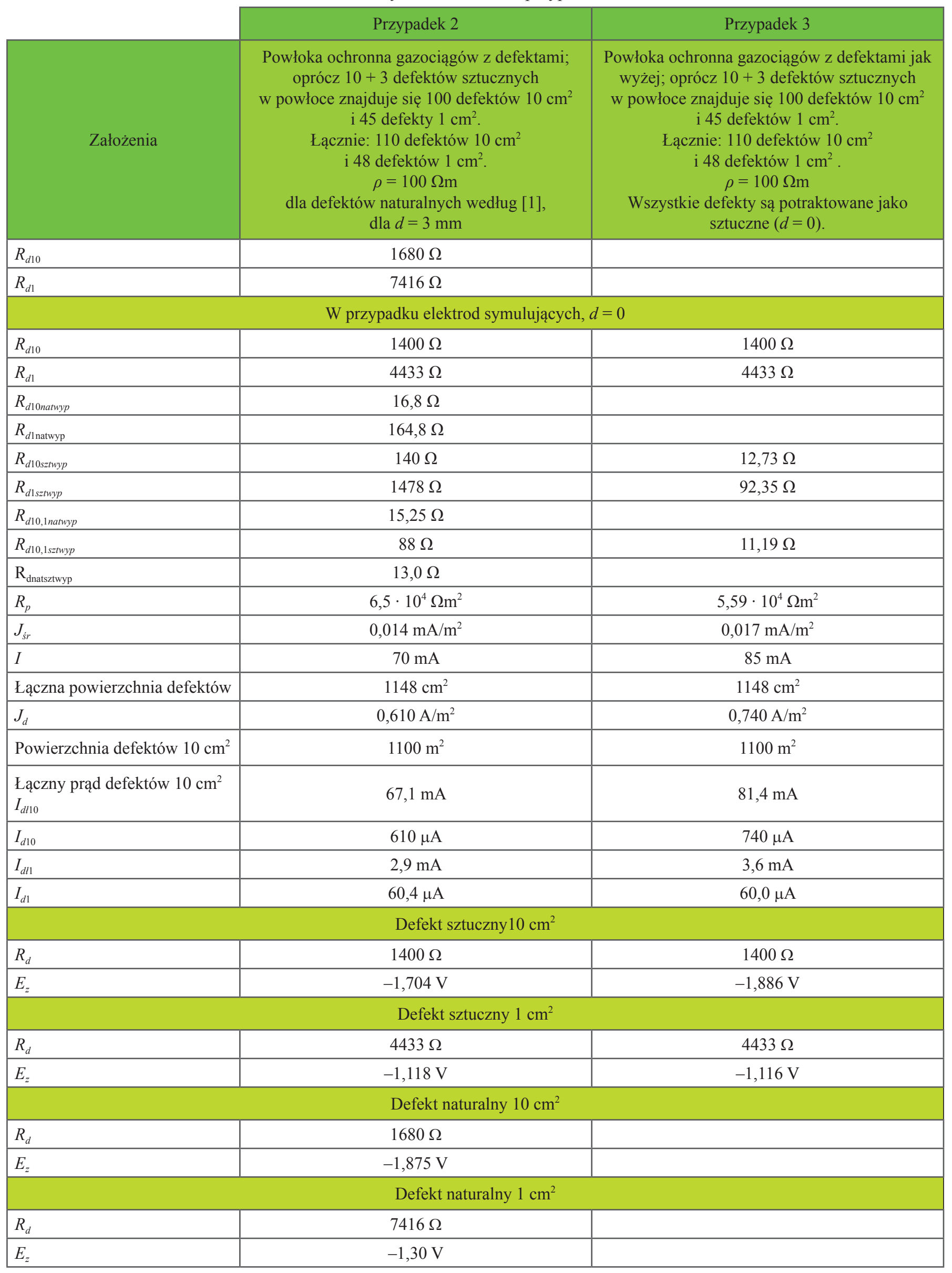




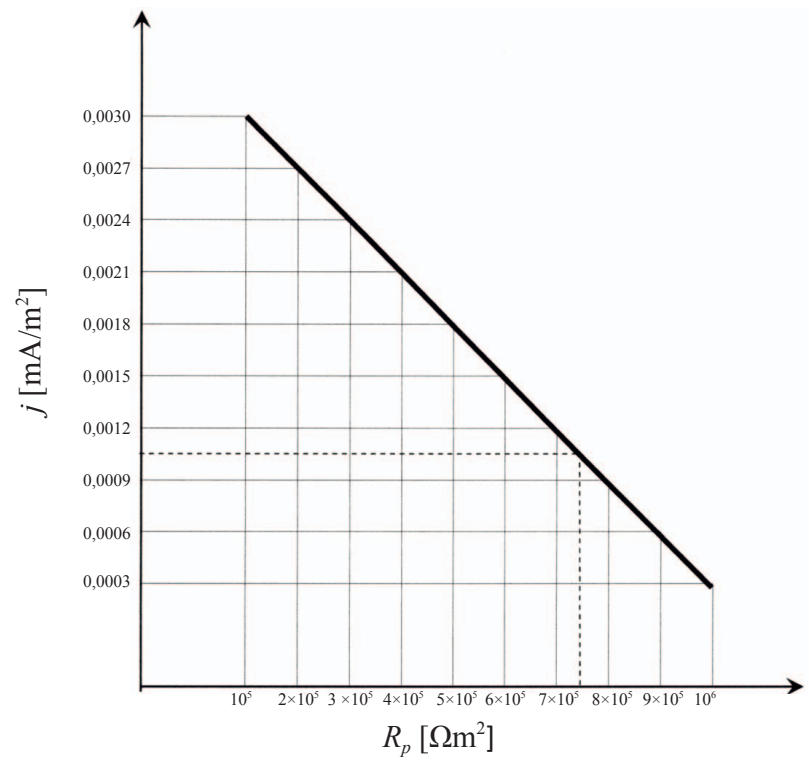

Rys. 4. Zależność średniej gęstości prądu ochrony katodowej od średniej jednostkowej rezystancji przejścia [7]

Gęstość prądu na powierzchni $10+3$ defektów o łącznej powierzchni $103 \mathrm{~cm}^{2}$ wynosi [8]:

$$
J_{d}=\frac{7,0 \cdot 10^{-3}}{103 \cdot 10^{-4}}=0,68 \mathrm{~A} / \mathrm{m}^{2}
$$

Prąd wpływający do defektu:

$$
I_{d}=\frac{E_{p}-E_{z}}{R_{d}}[A]
$$

gdzie: $E_{p}$ - potencjał ochrony katodowej w gruncie o danej rezystywności $\left(E_{p}=-0,85 \mathrm{~V}\right)$.

Defekt $10 \mathrm{~cm}^{2}$ :

$$
E_{z}=E_{p}-I_{d} \cdot R_{d}[V]
$$

$$
\begin{gathered}
I_{d}=0,68 \cdot 10 \cdot 10^{-4}=6,8 \cdot 10^{-4} \mathrm{~A}=680 \mu \mathrm{A} \\
R_{d}=1400 \Omega \\
E_{z}=-0,85-1400 \cdot 6,8 \cdot 10^{-4}=-0,85-0,952=-1,802 \mathrm{~V}
\end{gathered}
$$

Defekt $1 \mathrm{~cm}^{2}$ :

$$
\begin{gathered}
I_{d}=0,68 \cdot 1 \cdot 10^{-4}=0,68 \cdot 10^{-4} \mathrm{~A}=70 \mu \mathrm{A} \\
R_{d}=4433 \Omega
\end{gathered}
$$

$E_{z}=-0,85-4433 \cdot 0,68 \cdot 10^{-4}=-0,85-0,31=-1,16 \mathrm{~V}$

W tablicy 1 zestawiono wyniki obliczeń dla przypadków 2 i 3.

\section{Analiza wyników obliczeń}

1. Średnia jednostkowa rezystancja przejścia rurociągu oraz średnia jednostkowa gęstość prądu na powierzchni rurociągu są parametrami obliczeniowymi charakteryzującymi ogólnie stan powłoki ochronnej. O wartości średniej jednostkowej rezystancji przejścia może zadecydować zarówno pojedynczy defekt, jak i tysiące minidefektów czy drobnych pęknięć powłoki ochronnej. Wartość średniej jednostkowej rezystancji przejścia stanowi wymaganie projektowe. Sprawdzenie, czy zostało ono spełnione, odbywa się poprzez pomiary potencjałów i prądów rurociągu wykonywane w warunkach polaryzacji katodowej, często próbnej na odcinkach budowanego rurociągu.

Załączony wykres $j=f\left(R_{p}\right)$ dotyczy zakresu $R_{p}$ od $10^{5}$ do $10^{6} \Omega \mathrm{m}^{2}$. Przedstawiona liniowa zależność $j$ od $R_{p}$ obowiązuje oczywiście proporcjonalnie dla dowolnych zakresów rezystancji o krotności 10.

2. Z porównania przypadków 1 i 3 wynika, że:

- dziesięciokrotne zwiększenie liczby defektów, czyli dziesięciokrotny wzrost ich łącznej powierzchni, skutkuje dziesięciokrotnym obniżeniem średniej jednostkowej rezystancji przejścia i dziesięciokrotnym zwiększeniem średniej wymaganej gęstości prądu ochrony katodowej obiektu,

- gęstość prądu na powierzchni defektów pozostaje w obydwu przypadkach stała, tak samo jak wymagane potencjały załączeniowe defektów, odpowiednio: $10 \mathrm{~cm}^{2}$ i $1 \mathrm{~cm}^{2}$.

3. W przypadku 2, dotyczącym takiej samej łącznej liczby defektów jak przypadek 3, uwzględniono wpływ rezystancji elektrolitu w naturalnych defektach powłoki ochronnej rurociągu. Wpływ ten powoduje zwiększenie rezystancji defektu $10 \mathrm{~cm}^{2}$ o $20 \%$ oraz defektu $1 \mathrm{~cm}^{2}$ o $67 \%$. W rezultacie wypadkowa rezystancja wszystkich defektów i średnia jednostkowa rezystancja przejścia wzrastają o $21 \%$.

W konsekwencji o 21\% maleją: średnia gęstość prądu ochrony katodowej, zapotrzebowanie prądu ochrony katodowej oraz gęstość prądu na powierzchni defektów. Składowe IR sztucznych defektów maleją, a potencjały załączeniowe wzrastają (stają się mniej ujemne). Natomiast składowe IR naturalnych małych defektów $\left(1 \mathrm{~cm}^{2}\right)$ rosną wskutek znacznego wzrostu rezystancji, mimo spadku poboru prądu. W rezultacie potencjały załączeniowe małych defektów stają się bardziej ujemne. Składowe IR dużych defektów $\left(10 \mathrm{~cm}^{2}\right)$ pozostają praktycznie bez zmian, w związku z czym potencjały załączeniowe tych defektów też nie ulegają przekształceniom.

Powyższa analiza oparta jest na założonej liczbie i wielkości powierzchni defektów powłoki. Jeżeli mamy pewność, że jedynymi defektami powłoki są defekty sztuczne, 
możemy wiarygodnie wyznaczyć wartości wymaganego prądu ochrony katodowej defektów oraz wartości potencjałów załączeniowych defektów i również wiarygodnie zweryfikować pomiarowo wyznaczone wartości.

W olbrzymiej większości przypadków liczba i wielkości powierzchni defektów w powłoce izolacyjnej są nieznane. Nie można więc oceniać skuteczności ochrony katodowej rurociągu na podstawie wyników pomiarów potencjałów załączeniowych, ponieważ nieznane są składowe
IR mierzonych potencjałów. Jeżeli rurociąg jest umieszczony w jednorodnym gruncie i nie podlega oddziaływaniom obcych prądów, to wiarygodnym potencjałem, którego wartość można porównać z kryterium ochrony, jest potencjał wyłączeniowy mierzony bezpośrednio po wyłączeniu prądu ochrony katodowej. Jeśli powyższe warunki nie są spełnione, to należy mierzyć potencjały odłączeniowe sztucznych defektów i uzyskane wartości porównywać z potencjałowym kryterium ochrony katodowej.

Prosimy cytować jako: Nafta-Gaz 2016, nr 8, s. 638-644, DOI: 10.18668/NG.2016.08.08

Artykuł nadesłano do Redakcji 12.02.2016 r. Zatwierdzono do druku 12.04.2016 r.

\section{Literatura}

[1] Dietrich A.: Zastosowanie metody hierarchii analitycznej (AHP) do oceny poziomu bezpieczeństwa technicznego gazociagów. Nafta-Gaz 2010, nr 12, s. 1123-1131.

[2] Dietrich A., Badowski J.: System komputerowy oceny stanu technicznego i analizy ryzyka dla dystrybucyjnych sieci gazowych. Nafta-Gaz 2009, nr 11, s. 895-900.

[3] Markiewicz M., Machoń S.: Opracowanie metody kontroli skuteczności oraz wytycznych eksploatacji ochrony katodowej gazociagów. Praca Instytutu Górnictwa Naftowego i Gazownictwa (niepublikowana), listopad 1981.

[4] Minor T.: Wplyw prądów tellurycznych na potencjat względem ziemi stalowego podziemnego rurociagu. Nafta-Gaz 2014, nr 11, s. 794-801.

[5] Stochaj P.: Ochrona katodowa podziemnych gazociagów na obiektach kubaturowych - projektowanie i eksploatacja. Dokumentacja Instytutu Nafty i Gazu, Kraków 2004, nr zlecenia: 46/GP

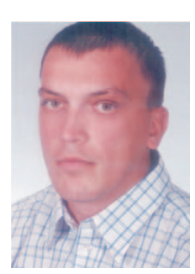

Mgr inż. Paweł STOCHAJ

Główny specjalista inżynieryjno-techniczny w Zakładzie Przesyłania i Dystrybucji Gazu, pracownik Laboratorium Badań Armatury i Technik Eksploatacji Gazociągów.

Instytut Nafty i Gazu - Państwowy Instytut Badawczy ul. Lubicz 25 A, 31-503 Kraków

E-mail: pawel.stochaj@inig.pl
[6] Stochaj P.: Ochrona zbiorników za pomoca anod galwanicznych. Nafta-Gaz 2010, nr 6, s. 493-499.

[7] Stochaj P.: Sondy pomiarowe w badaniach korozyjnych podziemnych konstrukcji. Dokumentacja Instytutu Górnictwa Naftowego i Gazownictwa, Kraków 2003, nr zlecenia: 48/GP.

[8] von Baeckmann W., Schwenk W., Prinz W.: Editors Handbook of Cathodic Corrosion Protection: Theory and Practice of Electrochemical Protection Processes. Third Edition. 1997.

\section{Akty prawne i normatywne}

[9] PN-EN 12954:2004 Ochrona katodowa konstrukcji metalowych $w$ gruntach lub $w$ wodach - Zasady ogólne $i$ zastosowania dotyczace rurociagów.

[10] PN-EN 13509:2005 Metody pomiarowe w ochronie katodowej.

[11] PN-EN 14505:2007 Ochrona katodowa konstrukcji złożonych.

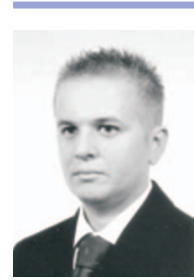

Mgr inż. Tomasz MINOR

Główny specjalista inżynieryjno-techniczny w Zakładzie Przesyłania i Dystrybucji Gazu, kierownik Laboratorium Badań Armatury i Technik Eksploatacji Gazociągów.

Instytut Nafty i Gazu - Państwowy Instytut Badawczy ul. Lubicz 25 A, 31-503 Kraków E-mail:tomasz.minor@inig.pl 